\title{
Instilling Healthy Lifestyle Behaviour into Prospective Physical Education Teachers through 30 Day Fitness Challenge Application
}

\author{
T Muhtar ${ }^{1}$, T Supriyadi $^{2}$, A Suherman ${ }^{3}$. \\ \{tatangmuhtar@upi.edu ${ }^{1}$ \} \\ Primary School Teacher Education of Physical Education Study Program, Sumedang Campus, \\ Universitas Pendidikan Indonesia, Sumedang Regency ${ }^{1,2,3}$
}

\begin{abstract}
The teachers are expected to develop the competencies in the mastery and utilization of ICT in the learning process. Therefore, this research aims at exploring the prospective physical education teachers' skills in the utilization of ICT in the learning process of physical education learning. The procedure of this research are: searching the application, understanding of the application, conducting the learning process through the application and evaluating the learning outcomes. This research was conducted in one of the universities in Sumedang Regency by involving 100 students of prospective physical education teachers. The findings revealed that the use of this application had an effect on healthy lifestyle behavior with the indicators. Therefore the utilization of the 30 Day Fitness Challenge application was able to instill the healthy lifestyle character in the prospective physical education teachers.
\end{abstract}

Keywords: Android-based application, Healthy lifestyle behaviors, Physical education

\section{Introduction}

As Law Number 20 of 2003 states that the goal of national education is to embody human beings who are physically and mentally healthy, the school is a place for character building and a media for instilling understanding and habit of a healthy life. In education, healthy lifestyle behaviors are essential to be developed in the learning process [1]. It means that physical education teachers have an important role because they are the spearhead in instilling the habit of a healthy life in their students. Healthy lifestyle behaviors are behaviors related to one's efforts to maintain and improve their health [2]. Some indicators of healthy lifestyle behaviors include regular exercise or physical activities, enough sleep, regular eating, good breakfast, weight control, and abstinence from cigarettes, alcohol, and illegal drugs [3, 4].

The era of information and communication technology that promises unlimited facilities to explore information leaves a number of problems, one of which is the alarming gadget addiction among young people, which can make them reluctant to do physical activities. They tend to prefer being idle to play with their gadgets than doing physical activities and socialize with others. This condition will certainly affect their health and fitness levels. From a survey conducted by the Ministry of Communication and Information, it was discovered that, of 88 million internet users, $64.81 \%$ of them were students consisting of $25.90 \%$ of 9 -15-year-old students and $38.91 \%$ of 16-25-year-old students [5]. Therefore, physical education teachers 
need to educate their students regarding the importance of healthy lifestyle behaviors in the learning process by utilizing Information and Communication Technology (ICT).

Previous studies on the application of ICT in physical education class have found that physical education teachers often face difficulties and obstacles in integrating technology in physical education class [6]. This is because they do not have sufficient digital competencies to develop ICT-related learning activities [7]. Therefore, teachers need to improve their competencies in integrating ICT in physical education class because, nowadays, ICT plays an important role in physical education. As revealed by Xianzhou, computer multimedia technology has promoted physical education significantly. This shall play a positive role in promoting the application of multimedia computers in physical education and training [8]. In addition to being able to use ICT as a source of learning, teachers are also required to be able to create creative and fun learning activities integrated with ICT. Creative and fun learning is very important because it can help students succeed in learning, offer solutions to solve problems, affect their lives, and give pleasure and satisfaction [8-12]. Thus, this research aims to explore the ability of the students as prospective physical education teachers in using ICT as a learning media, by utilizing an Android-based mobile phone application called the 30 Day Fitness Challenge application, to instill healthy lifestyle behaviors for the students.

\section{Methods}

This research was conducted in several stages, namely: (1) searching and downloading the android-based application related to physical education, (2) explaining the features of the 30 Day Fitness Challenge application, (3) conducting physical education classes using the 30 Day Fitness Challenge application, and (4) evaluating the learning processes that use the 30 Day Fitness Challenge application. The participants of this research include 100 undergraduate students in a university in Sumedang Regency, which consists of 35 female students and 65 male students who originated from various regions in West Java province.

\section{Results and Discussion}

\subsection{Searching and downloading the application}

This stage aims at finding an appropriate application to be used as learning media as an effort to instill healthy lifestyle behaviors. The healthy lifestyle behaviors here refers to a habit of doing physical activities to maintain fitness level. With that in mind, the 30 Day Fitness Challenge was selected. This application is developed by Leap Fitness Group and has been downloaded by 10 million users. It is designed to help the users improve their fitness and health, as well as effectively lose weight. With rules for exercise, the 30 Day Fitness Challenge can help the users gradually increase the intensity of their exercise and practice daily exercise more easily. Display of the application on Google Playstore can be seen in Figure 1. 


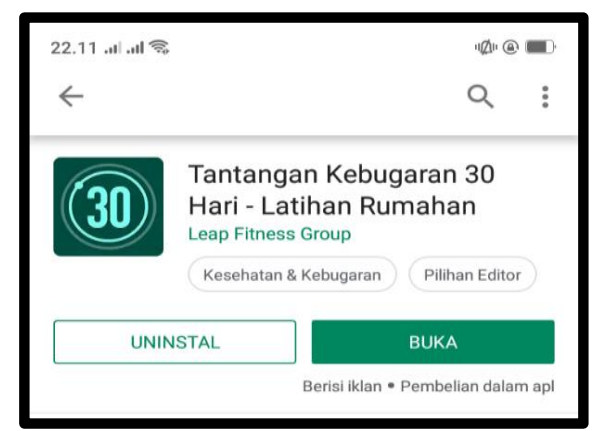

Fig. 1. Display of the Application on Google Playstore.

\subsection{Learning the application}

At this stage, the features of the application were explained to the students. The features are as follows:

Challenge Feature. This feature guides the users on the kinds of exercise they want to do. This feature is equipped with a planning system that uses didactic principles from easy to complex. Every plan is designed for 30 days with a guide on the kind of exercise to do, the number of movements, and the time needed to do the exercise every day. The number and time for each movement are adjusted to the user's weight and height. So, the users shall enter their weight and height on the application before choosing the exercise on the challenge feature. This feature is also able to remind the users when it is time to do their daily exercise. It can be seen in Figure 2.
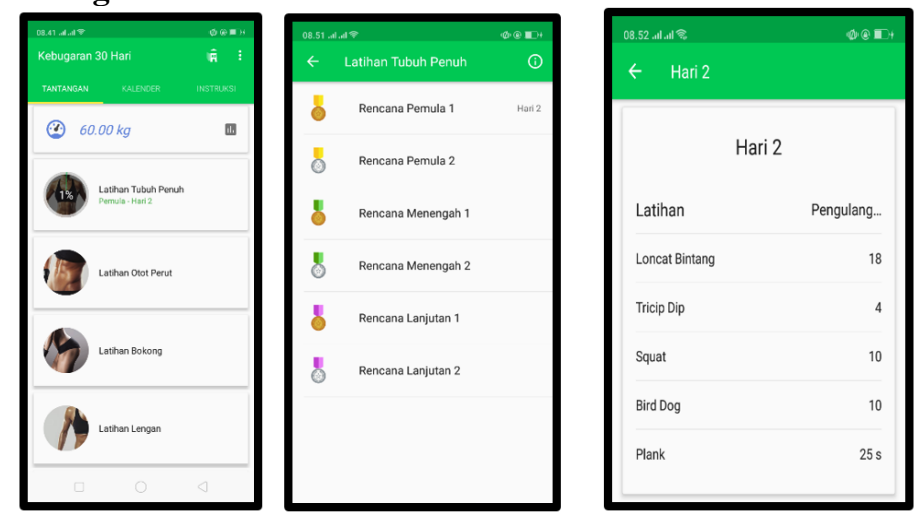

Fig. 2. Display of the Challenge Feature on the 30 Day Fitness Challenge Application.

Calendar Feature. This feature records the exercise in 30 days and presents the data about the exercise that the users do in the form of a statistical display. In addition, there is a weight measurement element in this feature to track the users' weight during the 30 days. It can be seen in Figure 3. 

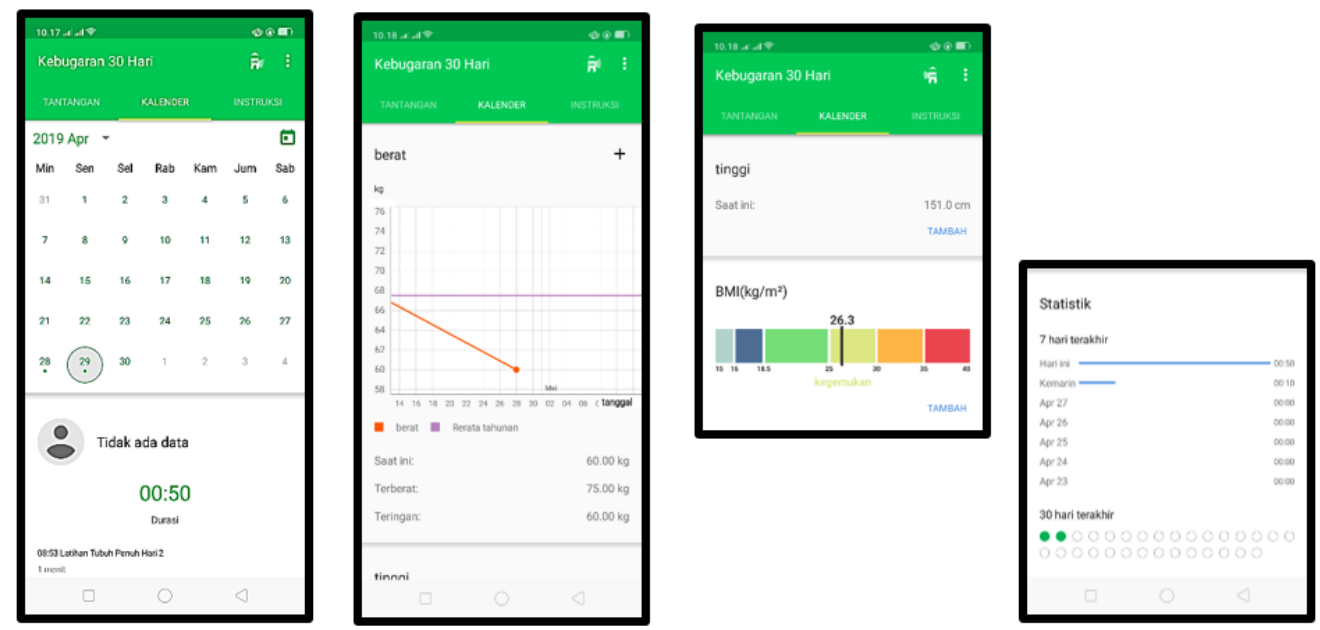

Fig. 3. Display of the Calendar Feature on the 30 Day Fitness Challenge Application.

Instruction Feature. This feature provides guidance for each exercise. For example, when the users choose full-body exercise in the challenge feature, they must refer to the instruction feature to see the movements included in this kind of exercise, such as jumping jack, tricep dip, and plank. Each movement is equipped with an instructional YouTube video that is connected to the application, it can be seen in Figure 4. Therefore, before doing the exercise, the users are expected to always refer to the instruction feature.
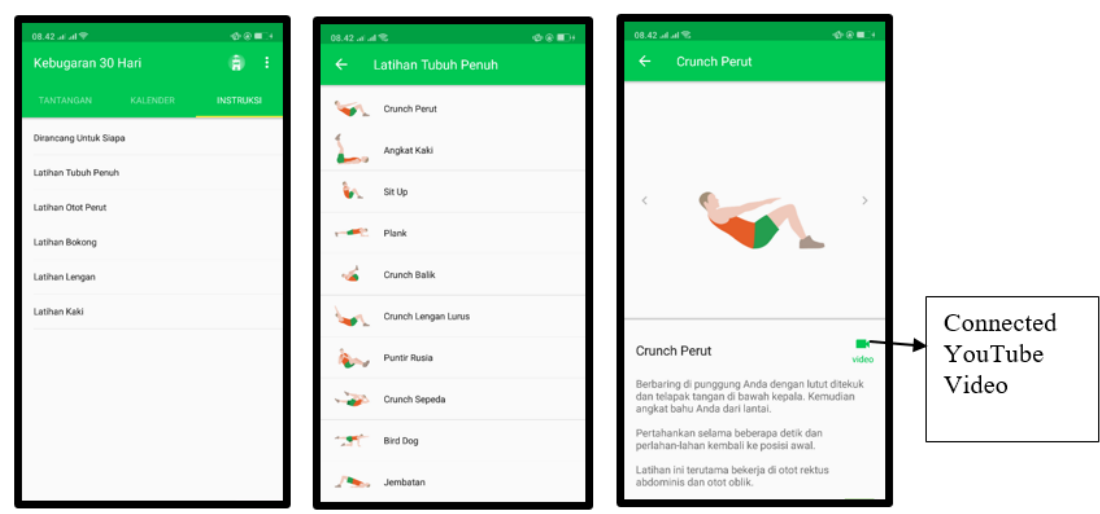

Fig. 4. Display of the Instruction Feature on the 30 Day Fitness Challenge Application.

\subsection{Using the application in the learning process}

The integration of the application in physical education class was conducted at this stage. After the students were instructed to install and learn each of the applications, they were instructed to plan their exercise for the next 30 days by selecting "full-body exercise" on the 
challenge feature. In the learning process, the students were instructed to follow the directions below:

1. Do the exercise in groups of five.

2. Make a daily report of the exercise with some pictures of them doing the exercise attached.

3. Submit the report every week in the class to the instructors for monitoring purposes.

4. Memorize the names of the movements on the application.

\subsection{Learning Evaluation}

This stage is the evaluation phase of the learning activities that have been done using the 30 Day Fitness Challenge application. The aspects that were being evaluated include the development of daily exercise habits, fitness level, and mastery of every movement. The evaluation results can be described as follows on Figure 5:

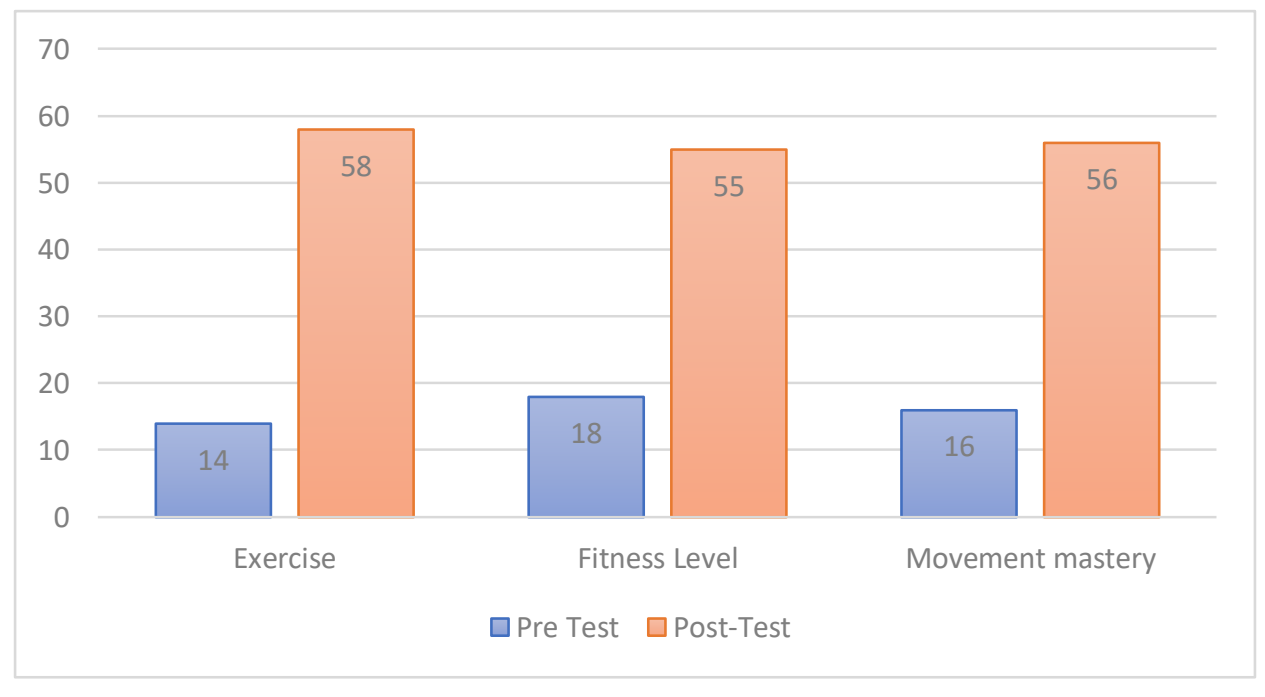

Fig. 5. Evaluation Result.

Based on the graph above, it can be seen that physical education learning using the 30 Day Fitness Challenge application can increase the students' active participation in realizing healthy lifestyle behaviors through regular exercise. This can also be seen from the pre-test and post-test results. In the pre-test, $14(23 \%)$ students stated that they do regular exercise; in the post-test, $58(96.6 \%)$ students stated that they do regular exercise. This means that there was an increase of 44 people $(73 \%)$. Moreover, increasing exercise habits had an impact on the fitness level. This can be seen from the number of students who were categorized as fit, which was $18(30 \%)$ students in the pre-test and $55(91.6 \%)$ students in the post-test. This means that there were an increase in physical fitness by $37(61.6 \%)$ students. Furthermore, in mastering the concepts and names of the movements in the exercise, the results of the pre-test showed only $16(26.6 \%)$ students mastered the names of the movements and the result of the post-test showed that $56(93 \%)$ students mastered the names of the movements. This means 
that physical education learning using the 30 Day Fitness Challenge application has improved the mastery of $40(66 \%)$ students regarding the concepts and names of the movements in the exercise.

\section{Conclusion}

Based on the stages taken and the findings obtained, it can be concluded that physical education learning using the 30 Day Fitness Challenge application can instill healthy lifestyle behaviors in prospective physical education teachers by making them accustomed to conducting organized, planned, and measurable exercise. The exercising habit can also serve as a therapy for the alarming gadget addiction in addition to instilling healthy lifestyle behaviors in the students, especially those enrolled in the physical education study program.

\section{References}

[1] Irwandi, S., N. Ufatin, and S.J.J.P.T. Sultoni, Penelitian, dan Pengembangan, Peran Sekolah Dalam Menumbuhkembangkan Perilaku Hidup Sehat Pada Siswa Sekolah Dasar (Studi Multi Situs Di SD Negeri 6 Mataram dan SD Negeri 41 Mataram Kota Mataram Nusa Tenggara Barat).2016. 1(3): p. 492-498.

[2] Sulistiarini, S., Hubungan Perilaku Hidup Sehat Dengan Status Kesehatan Pada Masyarakat Kelurahan Ujung. Jurnal Promkes: The Indonesian Journal of Health Promotion and Health Education (Jurnal Promosi dan Pendidikan Kesehatan Indonesia), 2018(1): p. 12.

[3] Departemen Kesehatan, R.J.J.D.K.R., Pedoman pemberantasan penyakit saluran pernafasan akut. 2002.

[4] Sharkey, B.J., Kebugaran dan Kesehatan.(eridesmarini nasution. Terjemahan). 2003, Jakarta: PT Raja grafindo Persada. .

[5] Komunikasi, K. and I.R.I. Indonesia, Buku Saku Survey Indikator Akses dan Penggunaan TIK pada Rumah Tangga Tahun 2014. 2014, Jakarta: Puslitbang PPI-Kominfo. Jakarta.

[6] Villalba, A., M.D. González-Rivera, and B.J.T.O.J.o.E.T.-T. Díaz-Pulido, Obstacles Perceived by Physical Education Teachers to Integrating ICT. 2017. 16(1): p. 83-92.

[7] María Fátima Torres, S., Inclusion of ICT in the area of Physical Education (3rd year of Primary Education). Tecnología, Ciencia y Educación, 2015(1): p. 84.

[8] Xianzhou, A., Innovative Physical Education Methods Based on Computer Technology. Educational Sciences: Theory \& Practice, 2018. 18(5): p. 2115-2123.

[9] Koryahin, V. and O. Blavt, The Use of Information and Communication Technology for Determining the Level Mobility in Joint in Physical Education of Students. Teoriâ ta Metodika Fìzičnogo Vihovannâ, 2018(3): p. 107.

[10] Liu, Y. and Y. Liu, The Influence of the Internet Sports Information on College Physical Education. 2018. 18(6): p. 2949-2957.

[11] Restiyani, R.J.E., Profil pemanfaatan teknologi informasi dan komunikasi (tik) sebagai media dan sumber pembelajaran oleh guru biologi. 2014. 6(1): p. 49-66.

[12] Wallhead, T., M.J.P.e. O'sullivan, and s. pedagogy, Sport education: Physical education for the new millennium? 2005. 10(2): p. 181-210. 